\title{
National Culture, IFRS Convergence, and The Accounting Quality: Evidence from EAGLEs Countries
}

\author{
ANISAH NOVI KARUNIA* \\ ATIKA NURFAUZIA \\ NUR ZAHRAH YULITANINGTIAS \\ Universitas Gadjah Mada
}

\begin{abstract}
This study aims to evaluate the influence of national culture on the relationship between IFRS convergence and accounting quality of companies in Emerging and Growth Leading Economies (EAGLEs) countries. This study uses measurements of accounting quality: earnings management, timely loss recognition, and value relevance. Cultural factors are measured using Gray's (1988) measurements. The sample in this study were 14 countries with a total of 6,832 observations in the 2012-2018 period. The data in this study used secondary data obtained from the Osiris Database. The results of this study provide evidence that accounting quality in EAGLE countries is positively related to the level of IFRS convergence, especially in earnings management and timely loss recognition. This shows that IFRS convergence can reduce earnings management and improve the timely loss recognition. Other results in this study, cultural factors, especially on the value of conservatism, partially support the relationship of IFRS convergence and accounting quality, while the value of secrecy is not supported.
\end{abstract}

Keywords: IFRS convergence, accounting quality, national culture, accounting standards, EAGLEs countries

\begin{abstract}
Abstrak: Studi ini bertujuan untuk mengevaluasi pengaruh budaya nasional pada hubungan antara konvergensi IFRS dan kualitas akuntansi perusahaan di negaranegara Emerging and Growth Leading Economies (EAGLE). Penelitian ini menggunakan pengukuran kualitas akuntansi: manajemen laba, pengakuan kerugian tepat waktu, dan relevansi nilai. Faktor budaya diukur dengan menggunakan pengukuran Gray (1988). Sampel dalam penelitian ini adalah 14 negara dengan total 6.832 pengamatan pada periode 2012-2018. Data dalam penelitian ini menggunakan data sekunder yang diperoleh dari Database Osiris. Hasil penelitian ini memberikan bukti bahwa kualitas akuntansi di negara-negara EAGLEs berhubungan positif dengan tingkat konvergensi IFRS, terutama dalam manajemen laba dan pengakuan kerugian tepat waktu. Hal ini menunjukkan bahwa konvergensi IFRS dapat mengurangi manajemen laba dan meningkatkan pengakuan kerugian tepat waktu. Hasil lain dalam penelitian ini, faktor budaya, terutama pada nilai konservatisme, sebagian mendukung hubungan konvergensi IFRS dan kualitas akuntansi, sedangkan nilai kerahasiaan tidak mendukung.
\end{abstract}


Kata kunci: Konvergensi IFRS, kualitas akuntansi, budaya nasional, standar akuntansi, negara-negara EAGELs

\section{Introduction}

This research investigates the effect of IFRS adoption on accounting quality moderated by cultural differences in Emerging and Growth Leading Economies (EAGLEs) countries. With the globalization of international financial markets, a standard that can harmonize accounting standards throughout the world is needed. To make the right decision, Investors and other stakeholders need accurate and transparent (Bryce et al., 2015). Therefore, the International Accounting Standards Board (IASB) develops the International Financial Reporting Standards (IFRS), which aim to harmonize financial accounting standards across countries. The European Union first adopted this initiative as of January 1, 2005, where all companies domiciled in the European Union must prepare a consolidated report following IFRS. To date, around 166 countries have adopted IFRS to harmonize accounting standards (IFRS-Foundation, 2018). However, the global adoption of IFRS may not be practical or appropriate, giving rise to other arguments against IFRS adoption. IFRS is a principle-based standard that provides flexibility; in some cases, excessive flexibility can increase earnings management, which leads to a decrease in accounting quality (Barth et al., 2008).

Some studies lately use various measurements to measure accounting quality such as earnings management, timely loss recognition, value relevance (Barth et al., 2008; Christensen et al., 2015; Dimitropoulos, 2013), accrual quality (Chen et al., 2010; and Bryce et al., 2015), earnings persistence (Fuad et al., 2018). Previous research has linked IFRS adoption to accounting quality in various countries with inconsistent research results. Several studies conclude that companies that adopt IFRS have higher quality information (Barth et al., 2008; Chen et al., 2010; Christensen et al., 2015; Dimitropoulos et al., 2013; Liu et al., 2011). For example, Chen et al. (2010) found that accounting quality indicators improved after the adoption of IFRS in the European Union (reduced earnings management, absolute discretionary accruals, and 
increased accruals quality). Studies from (Ahmed et al., 2013; Bryce et al., 2015; Duarte et al., 2015; Fuad et al., 2018) do not support the results of previous studies. Bryce et al. (2015) found that accounting quality did not significantly improve after the adoption of IFRS in Australia. However, the audit committee was more effective in promoting accounting quality based on IFRS from previous Australian GAAP.

In addition, previous studies still focus on countries in the European Union (Chen et al., 2010; Callao and Jarne, 2010; Gray et al., 2015), making it difficult to generalize the results of these studies to countries outside the European Union. Therefore, this research is useful to fill the gaps in the literature by studying the impact of accounting quality with the adoption of IFRS, which is moderated by cultural factors in Emerging and Growth Leading Economies (EAGLEs) countries. To our knowledge, there has been no research focused on companies in EAGLEs. EAGLEs are countries that are predicted to experience rapid economic growth over the next ten years (BBVA-2016 research report).

The quality of accounting tends to differ in different EAGLEs countries for several reasons. First, the rate and years of adoption of IFRS are very different among EAGLEs countries so that they may influence different accounting qualities. For example, China, India, and Indonesia have adopted national standards that are substantially in line with IFRS Standards but have not yet announced plans or schedules for full adoption (IFRS-Foundation, 2018). We expect accounting quality in EAGLEs to vary by country according to adoption status over time because the level of preparation for IFRS financial statement adoption varies in different countries (D'Arcy and Tarca 2018). We assume that companies that adopt or are more converging to IFRS adoption status are expected to have a better level of accounting quality compared to countries that have a lower level of convergence with IFRS. Second, Gray (1988) and Wijayana and Gray (2018) discuss the influence of cultural factors on accounting practices.

Several previous studies also discussed the indication of the influence of national culture on earnings management (Callen et al., 2011 and Han et al. 2008). Borker 
(2013) shows that cultural factors are determinants of IFRS adoption. In addition, previous studies also documented the role of culture in (1) the relationship between IFRS adoption and its impact on the cost of equity capital (Alan, 2018); (2) convergence of IFRS (Edeigba et al., 2019); (3) financial statement disclosures (Akman, 2013); accounting conservatism during the adoption of IFRS (Zeghal and Lahmar, 2018); earnings management after the adoption of IFRS (Gray et al., 2015). Our study examines whether informal institutional factors such as accounting values that are culturally derived, significantly influence the quality of accounting in companies registered in EAGLEs countries after starting to converge IFRS. The countries of EAGLEs come from different continents, and we hope that cultural values can explain variations in accounting quality across EAGLEs countries.

Our study uses companies across EAGLEs countries from 2012-2018. According to previous literature, there are many measurements of accounting quality. We limit the measurement of accounting quality to earnings management, timely loss recognition, and value relevance (Barth et al., 2008; Christensen et al., 2015; and Dimitropoulos, 2013). In addition, we also analyze the influence of culture on the relationship between IFRS convergence and accounting quality using Hofstede (2011), which refers to the study of Alan et al. (2018).

This research contributes in several ways. First, research related to IFRS convergence and accounting quality in international studies tends to focus on developed countries, especially the European Union. This study covered companies in developing countries that are included in the EAGLEs country group thus can add to the literature and offer the potential better to understand IFRS convergence and its relationship with accounting quality. Second, our research also focuses on informal institutional factors, where culture is expected to influence accounting quality in the context of IFRS convergence globalization.

The next part of this paper is organized as follows. Section 2 contains an explanation related to the theory and previous studies as a basis for developing hypotheses to be tested. The sample design and data collection and analysis methods 
are presented in section 3. In section 4, analysis and discussion of results will be presented. The last part, namely section 5, contains conclusions for this study.

\section{Theoretical Framework and Hypothesis Development.}

\subsection{IFRS and Accounting Quality}

IFRS is claimed to be a high-quality international accounting standard and can improve the quality of accounting reporting globally (IFRS-Foundation 2018). Several previous studies documented mixed results on the effect of IFRS on accounting quality. Some provide evidence that IFRS is able to reduce the level of earnings management and improve earnings quality. Barth et al. (2008) researched 21 countries (developed and developing) and found that IFRS had an impact on higher quality accounting. However, some studies do not support previous results (Ahmed et al. 2012; Bryce et al. 2015). Although there have been many studies on the effect of IFRS on accounting quality, it still focuses on developed countries with the full adoption of IFRS (Barth et al. 2008; Christensen et al. 2015; Bryce et al. 2015; Chen et al. 2010). Researches focus on developing countries that adopt gradually is still less explored.

The convergence of international accounting standards was first initiated by the International Accounting Standards Board (IASB) by issuing the International Accounting Standards (IAS, subsequently IFRS) in 1973 as a means of improving and harmonizing financial reporting worldwide (Bae et al., 2008). During the early adoption of IFRS, most of the countries that adopted IFRS were countries with advanced capital market characteristics such as the European Union and the United States. However, currently, IFRS has been adopted by several countries with emerging capital markets (Maradona \& Chand, 2018). Based on the data, 14 countries out of a total of 15 EAGLEs have converged IFRS in their countries, not simultaneously.

Previous research has tried to find evidence in developing countries individually and found some supporting evidence that IFRS is able to improve accounting quality (Qu et al. 2012; Vardia et al. 2016; Sustainable \& Takada 2015; Garcia et al. 2016). Research by Liu et al. (2011) provides empirical results, which generally indicate that accounting quality increases with reduced earnings management and increased 
relevance of accounting measurement values in China since 2007 after the convergence of IFRS. Wijayana and Gray (2018) found that the negative relationship between the level of IFRS convergence with earnings management was significant when the continued period of IFRS convergence while in the initial period did not find a significant relationship in line with the researchers' expectations. Research conducted by Hao et al. (2019) provides evidence that after the convergence of IFRS in China in 2006, the number of discretionary accruals increased, and the likelihood of companies reporting negative income was lower (timely loss recognition).

However, several other studies, especially in developing capital market countries, are not in line with the finding that accounting quality improves after the IFRS convergence (Wu et al. 2014; Rudra \& Bhattacharjee 2012; Indrawati 2015; Uwuigbe et al. 2016). Hassan (2009) examined the mandatory and voluntary disclosures made by companies after the IFRS convergence in Egypt and found that there was not enough evidence of the disclosure to be positively associated with value relevance. Research by Hessayri and Saihi (2015) who researched Saudi Arabia, Morocco, South Africa, and the Philippines also did not get sufficient evidence that earnings management would be lower after using IFRS reporting. Research conducted by Fuad et al. (2019) indicates that there is no real evidence that the dimensions of accounting quality, including accrual quality, earnings smoothing, timely loss recognition, and earnings persistence increase after IFRS convergence. In fact, the goal of the IASB according to Barth et al. (2008) is to provide high-quality standards and apply internationally by eliminating many accounting alternatives and providing measures that better reflect the economic position and performance of the company so that it will result in better information quality and accounting quality. Allegedly, differences in the effect of IFRS convergence on accounting quality in developing countries are due to variations in IFRS convergence itself in each country. Therefore, we suspect that accounting quality will positively associate with the level of IFRS convergence in developing countries, especially developing countries with major economic growth (EAGLEs). 
H1: The quality of accounting in EAGLEs countries is positively related to the degree of convergence of IFRS

\subsection{National Culture and Accounting Quality}

Collective programming of the mind that distinguishes the members of a group or category of someone from another defined as culture by Hofstede (2011). Hofstede began developing the cultural dimension in 1980 with four basic dimensions of culture: power distance, uncertainty avoidance, individualism, and masculinity. In the 1980s, based on Bond's research, Hofstede discovered the fifth dimension, Long-term Orientation ", while the sixth dimension, Indulgence, emerged during a study with Minkov in 2007 (Hofstede, 2011).

Several previous studies have tried to link national culture with accounting quality based on earnings management, timely loss recognition (conservatism), and value relevance. The research of Junior et al. (2018) found that in countries with high levels of uncertainty avoidance, individualism, masculinity, indulgence, and a longterm orientation, IFRS adoption can reduce the level of earnings management. Han et al. (2010) provide evidence that the level of individualism has a positive effect on earnings discretion, while uncertainty avoidance has a negative effect on earnings discretion. This indicates that countries with a high level of individualism have the potential to improve earnings management further, and countries with high uncertainty avoidance can reduce earnings management. In a study conducted by Paredes and Wheatley (2017) proved that (1) the higher the level of individualism and power distance, the higher the earnings management will be; (2) the higher the level of uncertainty avoidance and masculinity, it can reduce earnings management whereas Zeghal and Lahmar (2018) conducted research on culture related to conservatism and found evidence that there was a decrease in conditional conservatism when the level of uncertainty avoidance, power distance, and long-term orientation was high and when the level of individualism, masculinity, and indulgence was low. Whereas the reduction in unconditional conservatism only occurs when the level of power distance is high, and five other dimensions have no effect. 
With some findings from previous literature, Gray's (1988) cultural framework combining Hofstede's cultural dimensions with accounting values can help explain Hofstede's cultural dimensions $(1980 ; 1983 ; 2011)$ in measuring the quality of accounting information (Alan, 2018). There are four dimensions of Gray (1988): (1) Professionalism versus statutory: professionalism occurs when INDI levels are high with low UA and PD level; (2) Uniformity versus flexibility: uniformity occurs when the UA and PD levels are high, while the INDI level is low; (3) Conservatism versus optimism: conservatism occurs when the INDI and MASC levels are low while the UA level is high; and (4) Secrecy versus transparency: confidentiality occurs when UA and PD levels are high, but INDI and MASC levels are low.

EAGLEs countries consisting of developing countries spread over four continents have a high level of cultural difference. However, these countries adopted the same international standard, namely IFRS, so that cultural factors inherent with accounting values that are appropriate for looking at differences between countries are in terms of conservatism and secrecy. The higher ranks of uncertainty avoidance and the lower ranks of individualism and masculinity thus the more likely to have a higher rank in terms of conservatism and the higher rank in terms of uncertainty avoidance and power distance and the lower ranks of individualism and masculinity then likely to have a higher rank in terms of secrecy (Gray et al. 2015).

These preferences are consistent with those who have concerns about security and future needs; therefore, conservatives are adopted to overcome the uncertainty of the event. Conservatives will diminish when the level of individualism is high, which implies risk-taker preferences and also, secrecy preferences are consistent with the avoidance of strong uncertainty following the need to limit disclosure of information to avoid conflict and competition and to maintain security. Therefore, suspect that the convergence of IFRS will improve accounting quality when the conservatism level is high, and the secrecy level is low.

H2a: The positive relationship between IFRS convergence and accounting quality is strengthened by the value of conservatism accounting 
H2b: The positive relationship between IFRS convergence and accounting quality is weakened by secrecy accounting values

\section{Research Method}

\subsection{Research Sample and Data}

The research sample used came from companies in Emerging and Growth Leading Economies (EAGLEs), which are projected to experience rapid economic growth until the year 2022 (BBVA, 2016). The country will be the center of the best investment opportunities, such as India, Brazil, China, Indonesia, Mexico, Russia, Turkey, Bangladesh, Egypt, Iran, Malaysia, Nigeria, Pakistan, the Philippines and Vietnam (Khan et al. 2019). Vietnam is not known to have adopted IFRS from the fifteen EAGLE groups as its accounting standard.

This study uses a purposive sampling method with a sample consisting of manufacturing companies and registered in a sample of EAGLEs countries. The use of data from one industry will provide an analysis that avoids the effects of industry problems and is not appropriate to be compared with differences in the structure of its financial statements (Reichelt and Wang, 2010; Francis, 2011). Besides, this study uses the Jones model, which involves fixed assets in the accrual component in knowing earnings management conditions so that manufacturing companies are more precise. Researchers used several sample criteria in hypothesis testing, namely (1) registered companies in 2012-2018; (2) has a fiscal period that ends on December 31; (3) the availability of data used as a control variable; (4) availability of determinants of country-level differences, namely national culture, (5) availability of data for testing the resulting accounting quality.

We collected data for the 2012-2018 period from the Osiris Database to explore the extent of the impact of IFRS convergence and examine its effects on accounting quality and other specific variables. While the data for cultural values using the Gray dimension model (1988). We started in 2012 on the background of most developing countries starting to do IFRS convergence and ending in 2018, which shows the achievement of the IFRS convergence period. Based on the differences in IFRS 
adoption times from EAGLEs country groups, we divide the two phases in the convergence range without having to equate the year of adoption from each country. The division of the first phase between 2012-2014 and the second phase of 2015-2018 using 14 EAGLEs countries that have done convergence to IFRS.

Table 1.

Sample Selection Result

\begin{tabular}{lr} 
& Total \\
\hline Manufacturing companies registered in the State of EAGLEs in 2012-2018 & 35.707 \\
Less: &
\end{tabular}

Companies with incomplete data or do not present information related to the variables studied

\begin{tabular}{lc}
\hline Number of observations in 2012-2018 & $\mathbf{6 . 8 3 2}$ \\
\hline Number of research sample & $\mathbf{9 7 6}$ \\
\hline
\end{tabular}

\subsection{Hypothesis Testing and Measurement of Variables}

\subsubsection{Model Specifications}

This study uses a panel regression analysis to test the proposed hypothesis. Empirical studies in measuring accounting quality are still a challenge for accounting academics (Ji et al., 2017). However, several alternative measurement models are currently often used to assess accounting quality through three constructs, such as earnings management, timely loss recognition, and value relevance. The model is presented in three equations, which are used to test the dependent variable, namely, accounting quality (ACQ). Model of enterprise-level IFRS adoption (IFRS) and country-level cultural values (CULT) as test variables. The control variable uses company size (SIZE), leverage (LEV), changes in company sales (GRWTH), liquidity ratios (LR), net cash flow operating activities (CF), and changes in total liabilities (DISSUE). Here (equation model 1), as below:

$$
\begin{aligned}
& \text { ACQ } i, t=a o+a 1 \text { IFRSi } i, t+a 2 \text { CULT } i, t+a 3 \text { IFRS } X \text { CULT } i, t+ \\
& \text { an CONTROLSi } t+e i, t
\end{aligned}
$$




\subsubsection{Measurement of Accounting Quality}

We use three dimensions of measurement to determine earnings quality, namely earnings management, timely loss recognition, and value relevance. Our analysis is to compare the accounting quality of companies before and after the convergence of IFRS and identify the effects of national culture on the relationship between IFRS convergence and accounting quality.

1. Earnings management

We use discretionary accrual measurements with The Modified Jones Model with emphasis on total accruals as manipulation. Based on Dechow et al. (1995) considered that the Jones model is the best model to detect earnings management, and the results obtained are more accurate. The stages and regression equations used to calculate discretionary accruals are as follows:

Total Accruals $(\mathrm{TA})=$ Net Income - Cash Flow Operation.

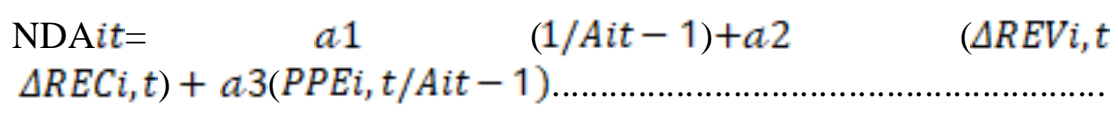

which, TAit $=$ Total accruals in the period $\mathrm{t}$; Ait $-1=$ Total assets of the company $\mathrm{i}$ in period $\mathrm{t} ; \triangle R E V i, t=$ Changes in company income $\mathrm{i}$ in period $\mathrm{t} ; \triangle \mathrm{REC}=$ Changes in company receivables $\mathrm{i}$ in period $\mathrm{t}$; and PPEi, $t=$ the value of the company's fixed assets $\mathrm{i}$ (Property, Plant, and Equipment) in period t.

$\mathrm{DAC}=$ TAit $/$ Ait $-\mathrm{NDA} i t$.

which, DACit $=$ Discretionary accrual of a company $\mathrm{i}$ in period $\mathrm{t}$, and NDAit= Discretionary accrual of the company $\mathrm{i}$ in period $\mathrm{t}$.

\section{Timely Loss Recognition}

We use the timely loss recognition measurement from Barth et al. (2008) in calculating logistic regression as testing hypotheses. Measurement of timely loss recognition is based on research from Basu (1997) and Lang et al. (2003) by regressing earnings per share (EPS) on indicator variables consisting of negative returns, stock returns, and interactions between returns and negative returns, with the following equation: 
EPSi, $\mathrm{t}=$ ao + a1DRi, $\mathrm{t}+\mathrm{a} 2 \mathrm{Ri}, \mathrm{t}+\mathrm{a} 3 \mathrm{R} * \mathrm{DR}+\mathrm{ei}, \mathrm{t}$

which, EPSi $i_{s} t=$ Earnings per share for the company i in period $t$; R $i_{s} t=$ Return of company stock $i$ in period $t$; DR $i_{s} t=$ Dummy variable, value 1 if the stock return for the company $\mathrm{i}$ in year $\mathrm{t}$ is negative and 0 otherwise; and $\mathrm{e}^{\mathrm{i}} \mathrm{t}, \mathrm{error}$ term.

3. Value relevance

The value relevance in this study was measured using a model from Barth et al. (2008), taking into account the adjusted $\mathrm{R}^{2}$ value. The regression equation that we use in testing value relevance with the equation is as follows

$$
P_{t}=\delta_{0}+\delta_{1} \text { BVPS }_{\text {it }}+\delta_{2} \text { EPS }_{\text {it }}+\varepsilon_{\mathrm{it}},
$$

which, $\mathrm{P}$ is the stock price of the company $\mathrm{i}$ in the period t; BVPS is book value per share in the company $i$ in period $t$, and EPS is the net income per share of the company $i$ in period $t$.

\subsubsection{International Financial Reporting Standards (IFRS)}

Previous studies used various methods and measurements in investigating the convergence of accounting standards to changes that have arisen over time that are already wide enough to reach Europe and the Asia-Pacific region (Christensen et al., 2015; Alan et al., 2018; Wijayana and Gray, 2019). This study uses a dummy variable at the company level by giving the number one for companies that have adopted the period and zero if they have not adopted IFRS. The researcher uses the company level model to obtain more relevant results to describe the condition of the company's accounting quality in the process of convergence to IFRS.

\subsubsection{Measurement of National Culture}

The cultural dimension becomes an interesting variable for the development of research, especially in accounting (Gray, 1988; Albuquerque et al., 2011; Borker, 2013; Kanagaretnam et al., 2014; Zeghal and Lahmar, 2018). We use the cultural dimension developed by Gray (1988) from Hofstade, which includes individualism, power distance, uncertainty avoidance, masculinity, long-term orientation, and indulgence. Gray argues that culture, as measured by Hofstede's cultural dimension, influences accounting values in various countries. We use the 
disclosure category of the cultural dimension developed by Gray (1988), which consists of secretion and conservatism. The development of the cultural dimension in the literature regarding the relationship of IFRS convergence and accounting quality is an interesting thing to explore, especially in the EAGLE group of countries and projections of investor protection.

\subsubsection{Measurement of Control Variables}

The control variable is used in this study to anticipate that the influence of the dependent variable is only affected by the main variable. Based on the previous literature, we use firm-level control variables, which are used to test significantly the factors that influence accounting quality. The following control variable in this study is shown in the following table 2.

Table 2.

Control Variables

\begin{tabular}{|c|c|c|c|c|}
\hline No & Variable & Definition/ Measurement & Reference & $\begin{array}{l}\text { Direction } \\
\text { Prediction }\end{array}$ \\
\hline 1 & $\begin{array}{l}\text { Firm } \\
(\mathrm{SIZE})\end{array}$ & $\begin{array}{l}\text { The natural logarithm of } \\
\text { total assets of firm } i \text { for } \\
\text { period } t\end{array}$ & $\begin{array}{lr}\text { Wattz } & \text { dan } \\
\text { Zimmerman } & 1978 ; \\
\text { Healy } & 1985 ; \text { Atiase } \\
1985 ; & \text { Bamber } \\
1987 & \end{array}$ & + \\
\hline 2 & Leverage (LEV) & $\begin{array}{l}\text { The leverage as measured } \\
\text { by the debt to equity ratio } \\
\text { (total debt to total assets) of } \\
\text { firm i for period t }\end{array}$ & $\begin{array}{l}\text { Defond } r \\
\text { Jiambalvo, 1994; } \\
\text { Francis and Wang, } \\
2008\end{array}$ & - \\
\hline 3 & $\begin{array}{l}\text { Growth } \\
\text { (GRWTH) }\end{array}$ & $\begin{array}{l}\text { The percentage change in } \\
\text { sales of firm } i \text { for period } t\end{array}$ & $\begin{array}{l}\text { McNichols, 2000; } \\
\text { Dechow et al, } \\
\text { 2006, 2010; Bart, } \\
\text { Landsman, and } \\
\text { Lang, 2008; Ze-To, } \\
2012\end{array}$ & - \\
\hline 4 & $\begin{array}{l}\text { Liquidity Risk } \\
\text { (LR) }\end{array}$ & $\begin{array}{l}\text { The liquidity risk as } \\
\text { measured by the average } \\
\text { liquidity ratio of firm i for } \\
\text { period } t\end{array}$ & $\begin{array}{l}\text { Wijayana and Grey } \\
2019\end{array}$ & - \\
\hline 5 & $\begin{array}{l}\text { Net Cash Flow } \\
\text { Operating } \\
\text { Activities }(\mathrm{CF})\end{array}$ & $\begin{array}{l}\text { The annual net cash flow } \\
\text { from operating activities of } \\
\text { firm i for period } t\end{array}$ & $\begin{array}{l}\text { Wijayana and Grey } \\
2019\end{array}$ & + \\
\hline 6 & $\begin{array}{l}\text { Debt Issuance } \\
\text { (DISSUE) }\end{array}$ & $\begin{array}{l}\text { The percentage change in } \\
\text { total liabilities of firm i for } \\
\text { period } t\end{array}$ & Chua et al, 2012 & $?$ \\
\hline
\end{tabular}




\section{Results and Discussion}

\subsection{Descriptive Statistic}

This study uses 6.832 observations consisting of 976 manufacturing companies in 14 countries of EAGELs. The total sample of the company consists of Bangladesh as many as 15, Brazil 22, China 331, Egypt 23, India 232, Indonesia 32, Iran 89, Malaysia 17, Mexico 20, Pakistan 30, Philippines 17, Russia 4, Nigeria 107, and Turkey 37.

Table 3 shows the results of descriptive statistical testing of the research variables involved in this study. Descriptive statistics are presented in the form of minimum, maximum, mean, and standard deviation of each research variable. Descriptive statistical results show that the average discretionary accrual in the first phase of IFRS convergence of -2.396 is greater than the second phase of -8.008 . Changes in the average discretionary accrual indicate the IFRS convergence process can reduce earnings management actions in EAGELs countries.

The accounting quality measure of timely loss recognition also shows an average of the first phase of IFRS convergence of 0.285 , increasing to 0.323 in the second phase. This indicates an increase in timely loss recognition during the IFRS convergence period. In addition, the measurement of accounting quality in the aspect of value relevance is known to have an average increase from 3.734 in the first phase to 6.408 in the second phase of IFRS convergence. The results show that the more consistent application of IFRS convergence will increase the value of relevance, which will affect the resulting increase in accounting quality. 
Tabel 3 .

Descriptive Statistic

\begin{tabular}{|c|c|c|c|c|c|c|c|c|}
\hline \multirow[b]{2}{*}{ Variable } & \multicolumn{4}{|c|}{$\begin{array}{c}\text { Phase } 1(2012-2014) \\
n=2.928\end{array}$} & \multicolumn{4}{|c|}{$\begin{array}{c}\text { Phase } 2(2015-2018) \\
n=3.904\end{array}$} \\
\hline & Min. & Max. & Mean & Std. Dev. & Min. & Max. & Mean & Std. Dev. \\
\hline \multicolumn{9}{|c|}{ Panel A. Measurement of Accounting Quality } \\
\hline DAC & -7.302 & 6.125 .21 & -2.396 & 220.463 & $-33,188.35$ & $3,093.82$ & -8.008 & 540.765 \\
\hline $\mathrm{TL}$ & -18.49 & 118.19 & 0.285 & 2.578 & -13.87 & 89.20 & 0.323 & 2.233 \\
\hline VR & 0.00 & 312.97 & 3.734 & 14.627 & 0.00 & $1,131.73$ & 6.408 & 32.51 \\
\hline \multicolumn{9}{|c|}{ Panel B. Measurement of IFRS \& Culture } \\
\hline IFRS & 0 & 1 & 0.25 & 0.430 & 0 & 1 & 0.34 & 0.474 \\
\hline CNSR VT & -64 & 20 & -41.32 & 24.577 & -64 & 20 & -41.32 & 24.575 \\
\hline SECRCY & 13 & 113 & 37.50 & 23.579 & 13 & 113 & 37.50 & 23.578 \\
\hline \multicolumn{9}{|c|}{ Panel C. Control Variable } \\
\hline SIZE & -0.002 & 0.553 & 0.080 & 0.089 & 0.00 & 19.17 & 12.748 & 1.916 \\
\hline LEV & 0.11 & 5.44 & 1.03 & 0.891 & -895 & 989 & 53.68 & 94.163 \\
\hline GRWTH & -1.00 & 370.30 & 0.2601 & 7.357 & -1.00 & 82.16 & 0.133 & 1.8 \\
\hline LR & 0 & 32 & 1.34 & 1.873 & 0 & 48 & 1.52 & 2.027 \\
\hline $\mathrm{CF}$ & $-1,081,701.78$ & $37,153,367.64$ & $137,513.38$ & $1,015,767.39$ & $-1,059,708.82$ & $30,116,886.53$ & $151,139.4427$ & $786,056.31902$ \\
\hline DISSUE & -1.00 & $3,845.04$ & 3.55 & 92.97 & -1.00 & 937.99 & 1.09 & 0.875 \\
\hline
\end{tabular}




\subsection{Hypothesis Test}

\subsubsection{Accounting Quality Test}

a. Earnings Management

Tests on changes in the level of earnings management using a discretionary accrual proxy calculated with the modified Jones model. Before conducting a different test, a normality test is first performed to determine the type of test to be used. If the data is normally distributed, then the test uses a paired sample ttest, but if the data is not normally distributed with the Wilcoxon Signed Ranks Test. After the normality test is known, the data of the first and second phases are not normally distributed. So a different test is done using Wilcoxon Signed Ranks. Wilcoxon Signed Ranks Test results for discretionary accruals in the first and second phases are shown in the following table 4 .

Table 4.

Statistical Value of the Wilcoxon Signed Ranks Test

\begin{tabular}{l|r} 
& \multicolumn{2}{|c}{ DAC_2-DAC_1 } \\
\hline Z & \\
Asymp Sig. (2 tailed) & 0.001 \\
\hline
\end{tabular}

Based on the table above, it appears that the Asymp. Sig. Value (2-tailed), which is 0.001 smaller than alpha (0.05). It can be concluded that there are differences in the level of earnings management in phase one and phase two. By the average value of DAC obtained the first phase of $-2,396$ higher than the average value of DAC in phase two of $-8,008$. This proves that the level of earnings management in the second phase is lower or decreases. The results of this study are in line with research by Barth et al. (2008), which states that companies that perform IFRS convergence have higher accounting quality because of a decline in the level of earnings management practices. IFRS convergence can reduce the level of earnings management because IFRS standards emphasize the principle of a transaction at the time of recording to 
reduce the opportunistic behavior of management in determining accounting policies that are applied to a company in EAGELs.

b. Timely Loss Recognition

The coefficient value of the interaction between the bad news indicator (negative return) and return in the first phase is -1.085 smaller than the coefficient value in the second phase, which is 0.471 . This shows that the recognition of losses is more time when the IFRS converges over a more extended period. Structurally the Chow test shows that there is a change between the first and second phases. These changes show that the results of the calculated $F$ value of 5.36 are greater than the $F$ table value of 3.00. Thus, the convergence of IFRS in EAGLEs is able to get companies to admit bad news early. Following the statement of Barth et al. (2008) that one of the characteristics of high earnings quality is the emergence of greater loss recognition. If in a company, it is found that the recognition of large losses that are relatively rare shows an indication of high-income smoothing.

c. Value Relevance

The first phase adjusted $\mathrm{R}$ square value of $-0,001$ is smaller than the second phase adjusted $R$ square value, which is 0.002 . This shows that the value relevance is higher when the convergence of IFRS standards is applied over a more extended period. Structurally, there is no change between the first and second phases. This can be seen from the calculated $F$ value of -13.63 less than the $\mathrm{F}$ table value of 3.00. Thus, the convergence of IFRS in EAGLEs countries has not yet fully influenced value relevance. This is because there are still many companies in EAGLEs that use local GAAP, and there is still no consistency in using applicable accounting standards, namely IFRS. For example, the BEXIMCO PHARMACEUTICALS LIMITED company in Bangladesh in 2012-2014 used IFRS, but in 2015 and 2017 again used local GAAP. However, IFRS was again used in 2018. 
From the previous discussion, it was found that more and more consistent a company in EAGLEs countries in implementing IFRS convergence, although it did not increase significantly in terms of value relevance. However, these conditions can reduce earnings management practices and increase the recognition of losses on time following Barth et al. (2008). Overall it can be concluded that there is a significant positive relationship between the level of IFRS convergence and the quality of corporate accounting in EAGLEs countries. Therefore hypothesis 1 is partially supported.

Table 5.

Differences in Value Relevance between Phase 1 and Phase 2 of IFRS Convergence

\begin{tabular}{lcc}
\hline Variable & $(1)$ & $(2)$ \\
& Phase 1 & Phase 2 \\
& $(2012-2014)$ & $(2015-2018)$ \\
\hline BVPS & -0.004 & $0.079 * * *$ \\
& $(-0.204)$ & $(2.710)$ \\
EPS & 0.001 & -0.035 \\
& $(0.037)$ & $(-1.211)$ \\
Adjusted $R^{2}$ & -0.001 & 0.002 \\
$\mathrm{~N}$ & 2.928 & 3.904 \\
\hline
\end{tabular}

\subsubsection{Testing the Role of Cultural Moderating}

Table 6 shows the results of OLS regression based on the main model in equation 1, namely, measurement of accounting quality (ACQ) using earnings management, timely loss recognition, and value relevance. Detecting the value and direction of the main effect is done by using OLS regression.

Panel A regression results on the dependent variable of accounting quality consisting of three proxies (earnings management, timely loss recognition, and value relevance) show results that support some of the hypothesis $2 \mathrm{a}$. The results show that the effect of conservatism accounting values on IFRS convergence relations and accounting quality is increasingly insignificant from the first phase to the second phase. This is because the conceptual framework of IFRS is not under the conservatism principle. It was proven that the first phase on the proxy for timely and acknowledgment of loss was still significant, respectively $5 \%$ and $10 \%$, 
but after the second phase, it was not significant. The first and second phases of the earnings management proxy are not significant.

Panel B shows the results that the effect of accounting value secrecy on the IFRS convergence relationship and accounting quality is getting stronger, except for the proxy of earnings management. So hypothesis $2 b$ is not supported. The results indicate that IFRS convergence in EAGELs countries encourages disclosures that tend to be less transparent so that it can reduce accounting quality. This is because companies in EAGELs countries are not consistent in making IFRS convergence, as evidenced by the results of hypothesis 1 on the proxy of value relevance that is not supported. The creation of value relevance is influenced by consistent efforts to apply IFRS as an applicable accounting standard. The more consistent the IFRS convergence will encourage more transparent disclosures so that it will improve accounting quality. 
Tabel 6

Regression Result

\begin{tabular}{|c|c|c|c|c|c|c|}
\hline $\begin{array}{l}\text { Differences in V } \\
\text { Panel A: Effects }\end{array}$ & $\frac{\text { levance } b}{\text { ural Con }}$ & sse 1 and & of IFRS C & ence & & \\
\hline Variable & Earnin & nent & Timely Lo & gnition & Value & nce \\
\hline & (1) & (2) & (1) & (2) & (1) & (2) \\
\hline IFRS & 0.007 & -0.014 & $0.135 * * *$ & $0.085 * *$ & $0.099 * * *$ & $0.116^{* * *}$ \\
\hline & $(0.227)$ & $(-0.447)$ & $(4.296)$ & $(2.793)$ & $(3.135)$ & $(3.828)$ \\
\hline CNSRVT & 0.002 & $0.034 *$ & $-0.133 * * *$ & $-0.054 * *$ & $-0.061 * *$ & $-0.057 * *$ \\
\hline & $(0.079)$ & (1.614) & $(-5.519)$ & $(-2.589)$ & $(-2.506)$ & $(-2.709)$ \\
\hline IFRS $*$ CNSRVT & 0.003 & -0.029 & $0.049 * *$ & 0.036 & $0.046^{*}$ & -0.012 \\
\hline & $(0.116)$ & $(-0.892)$ & (1.744) & (1.109) & $(1.622)$ & $(-0.377)$ \\
\hline SIZE & 2.928 & $0.030 *$ & $0.057 * *$ & $-0.061 * * *$ & $-0.072 * * *$ & -0.005 \\
\hline & & (1.684) & $(2.983)$ & $(-3.442)$ & $(-3.751)$ & $(-0.307)$ \\
\hline LEV & 0.019 & $-0.38^{* *}$ & $-0.062 * * *$ & -0.009 & 0.010 & -0.014 \\
\hline & $(0.993)$ & $(-2.323)$ & $(-3.284)$ & $(-0.537)$ & $(0.546)$ & $(-0.855)$ \\
\hline GRWTH & 0.000 & 0.002 & 0.019 & 0.025 & 0.018 & -0.005 \\
\hline & $(-0.008)$ & $(0.127)$ & (1.013) & (1.542) & $(0.973)$ & $(-0.285)$ \\
\hline LR & 0.003 & 0.009 & 0.017 & -0.007 & -0.012 & $0.045 * *$ \\
\hline & $(0.155)$ & $(0.557)$ & $(0.916)$ & $(-0.418)$ & $(-0.633)$ & $(2.771)$ \\
\hline $\mathrm{CF}$ & 0.007 & -0.008 & -0.018 & $0.064 * * *$ & -0.004 & -0.002 \\
\hline & $(0.343)$ & $(-0.465)$ & $(-0.969)$ & (2.793) & $(-0.221$ & $(-0.109)$ \\
\hline DISSUE & 0.001 & 0.000 & 0.009 & 0.003 & $0.051 * *$ & -0.004 \\
\hline & $(0.046)$ & $(0.018)$ & $(0.465)$ & $(0.215)$ & (2.737) & $(-0.264)$ \\
\hline
\end{tabular}


Panel B: Cultural Effects of Secrecy

\begin{tabular}{|c|c|c|c|c|c|c|}
\hline \multirow[t]{2}{*}{ Variable } & \multicolumn{2}{|c|}{ Earnings Management } & \multicolumn{2}{|c|}{ Timely Loss Recognition } & \multicolumn{2}{|c|}{ Value Relevance } \\
\hline & (1) & (2) & (1) & (2) & (1) & (2) \\
\hline \multirow[t]{2}{*}{ IFRS } & 0.005 & 0.030 & $0.201 * *$ & -0.015 & $0.125^{*}$ & $0.083 * *$ \\
\hline & $(0.074)$ & $(0.955)$ & $(2.832)$ & $(-0.461)$ & $(1.751)$ & $(2.652)$ \\
\hline \multirow[t]{2}{*}{ SECRCY } & 0.002 & 0.034 & $-1.114 * * *$ & $-0.052 * *$ & $-0.053 * *$ & $-0.063 * *$ \\
\hline & $(0.092)$ & $(1.537)$ & $(-4.703)$ & $(-2.396)$ & $(-2.153)$ & $(-2.883)$ \\
\hline \multirow[t]{2}{*}{ IFRS*SECRCY } & -0.001 & -0.031 & -0.097 & $0.097 * *$ & -0.055 & $0.061 *$ \\
\hline & $(-0.008)$ & $(-0.850)$ & $(-1.290)$ & $(2.640)$ & $(-0.727)$ & (1.678) \\
\hline \multirow[t]{2}{*}{ SIZE } & -0.001 & $0.029 *$ & $0.057 * *$ & $-0.060 * * *$ & $-0.072 * * *$ & -0.006 \\
\hline & $(-0.031)$ & (1.607) & $(2.982)$ & $(-3.420)$ & $(-3.753)$ & $(-0.350)$ \\
\hline \multirow[t]{2}{*}{ LEV } & 0.019 & $-0.038 * *$ & $-0.063 * * *$ & -0.011 & 0.012 & -0.017 \\
\hline & (1.012) & $(-2.309)$ & $(-3.340)$ & $(-0.670)$ & $(0.612)$ & $(-1.048)$ \\
\hline \multirow[t]{2}{*}{ GRWTH } & 0.000 & 0.002 & 0.019 & 0.025 & 0.018 &,- 0.004 \\
\hline & $(-0.010)$ & $(0.120)$ & $(1.027)$ & (1.587) & $(0.971)$ & $(-0.249)$ \\
\hline \multirow[t]{2}{*}{ LR } & 0.003 & 0.008 & 0.017 & -0.010 & -.0 .013 & $0.043 * *$ \\
\hline & $(0.148)$ & $(0.510)$ & (0.909) & $(-0.619)$ & $(-0.668)$ & $(2.620)$ \\
\hline \multirow[t]{2}{*}{$\mathrm{CF}$} & 0.007 & -0.008 & -0.009 & $0.061 * * *$ & 0.002 & -0.005 \\
\hline & $(0.351)$ & $(-0.447)$ & $(-0.498)$ & $(3.543)$ & $(0.103)$ & $(-0.291)$ \\
\hline \multirow[t]{2}{*}{ DISSUE } & 0.001 & 0.000 & 0.010 & 0.003 & $0.050 * *$ & -0.004 \\
\hline & $(0.035)$ & $(0.006)$ & $(0.527)$ & $(0.171)$ & $(2.712)$ & $(-0.240)$ \\
\hline
\end{tabular}




\section{Conclusion, Implication, and Limitation}

\subsection{Conclusion}

This research proves the results of Barth et al. (2008) that IFRS convergence can improve accounting quality. However, our findings on value relevance were not found to be statistically significant due to the inconsistency of countries in EAGELs in implementing IFRS convergence. Overall our findings are consistent with Barth et al. (2008). We also examine the influence of culture as a moderating variable on the relationship between IFRS convergence and accounting quality. The cultural factors that we use, namely conservatism and secrecy.

Our findings support part of hypothesis $2 \mathrm{a}$ that the influence of conservatism culture strengthens the positive relationship between IFRS convergence and accounting quality only in the first phase. In contrast, for the second phase, it does not show a significant relationship. The value of conservatism is not significant in the second phase proving the relationship of IFRS convergence with accounting quality because IFRS accounting standards are not currently relevant to the conservatism principle. Accounting quality based on IFRS must reflect understandable, relevance, reliable, comparable, and not conservative bias. The unsupported hypothesis $2 \mathrm{~b}$ indicates the influence of cultural values secrecy, reinforcing the positive relationship between IFRS convergence and accounting quality. Secrecy value does not show a negative effect due to the fact that companies in EAGELs countries that have not been consistent in carrying out IFRS conversions are proven to have weakened value relevance in accordance with the results of hypothesis 1 .

\subsection{Limitation and Suggestions Research}

This study has several limitations; namely, the research period is only limited to the 2012-2018 period to determine the development of IFRS convergence in developing countries, namely EAGELs (Emerging and Growth Leading Economies). The researcher should be able to further test the financial sector by using a measure of accounting quality in accordance with the conditions of the type of company. 


\section{Acknowledgments}

We would like to express our deep gratitude to Mr. Singgih Wijayana, Ph.D and Mrs. Ratna Nurhayati, Ph.D. as our research supervisors, for the patient guidance, encourangement and useful critiques of this research work. Our thanks are also to Magister and Doctoral FEB UGM form help us by providing resources to get the data in order to complete our research. Finally, we would like to thank the Seminar Penelitian Akuntansi Keuangan Class for their suggestions during the research process.

\section{Reference}

Ahmed, Anwer S, Michael Neel, and Dechun Wang. 2012. "Does Mandatory Adoption of IFRS Improve Accounting Quality? Preliminary Evidence." Contemporary Accounting Research, Vol. XX(X): 1-30.

Akman, Nazlı Hosal. 2011. "The Effect of IFRS Adoption on Financial Disclosure: Does Culture Still Play A Role?” American International Journal of Contemporary Research 1(1): 6-17.

Atiase, Rowland Kwame. 2016. "Predisclosure Information, Firm Capitalization, and Security Price Behavior Around Earnings Announcements Author ( S ): Rowland Kwame Atiase University of Chicago Stable URL: http://www.jstor.org/stable/2490905 Predisclosure Information, Firm Capital." Journal of Accounting Research 23(1): 21-36.

Bae, Kee-Hong, Hongping Tan, and Michael Welker. 2008. "International GAAP Differences: The Impact on Foreign Analysts." The Accounting Review 83(3): 593-628.

Ball, Rau, and Lakshmanan Shivakumar. 2006. "The Role of Accruals in Asymmetrically Timely Gain and Loss Recognition.” Journal of Accounting Research 44(2): 207-42.

Ball, Ray, and Lakshmanan Shivakumar. 2005. "Earnings Quality in UK Private Firms: Comparative Loss Recognition Timeliness." Journal of Accounting and Economics 39(1): 83-128.

Bamber, Linda Smith. 1987. "Unexpected Earnings, Firm Size, and Trading Volume around Quarterly Earnings.” The Accounting Review 62(3): 510-32.

Barth, Mary E, William H Beaver, and Wayne R Landsman. 2001. "The Relevance of the Value-Relevance Literature for Financial Accounting Standard Setting." Journal of Accounting and Economics 31(1-3): 3-75. 
Barth, Mary E, Warne R Landsman, and Mark H Lang. 2008. "International Accounting Standards and Accounting Quality." Journal of Accounting Research 46(3): 467-98.

Basu, Sudipta. 1997. "The Conservatism Principle and the Asymmetric Timeliness of Earnings." Journal of Accounting and Economics 24: 3-37.

BBVA Research, BBVA. 2016. "Emerging and Growth Leading Economies."

Beneish, Messod D. 2001. "Earnings Management: A Perspective." Managerial Finance 27(12): 3-17.

Borker, David R. 2012a. "Accounting, Culture, and Emerging Economies: IFRS In Central and Eastern Europe." International Business \& Economics Research Journal 11(9): 100318.

- 2012b. "Accounting, Culture, And Emerging Economies: IFRS In The BRIC Countries." Journal of Business \& Economics Research 10(5): 313-24.

- 2013. "Accounting And Cultural Values: IFRS In 3G Economies." International Business \& Economics Research Journal 12(6): 671-86.

Bryce, Mitchell, Muhammad Jahangir Ali, and Paul R Mather. 2015. "Pacific-Basin Finance Journal Accounting Quality in the Pre- / Post-IFRS Adoption Periods and the Impact on Audit Committee Effectiveness - Evidence from Australia." Pacific-Basin Finance Journal 35: 163-81. http://dx.doi.org/10.1016/j.pacfin.2014.12.002.

Callao, Susana, and José Ignacio Jarne. 2010. "Have IFRS Affected Earnings Management in the European Union? Have IFRS Affected Earnings Management in the European Union?" Accounting in Europe 7(2): 159-89.

Callen, Jeffrey L, Mindy Morel, and Grant Richardson. 2010. "Do Culture and Religion Mitigate Earnings Management? Evidence from a Cross-Country." International Journal of Disclosure and Governance 8(2): 103-21. http://dx.doi.org/10.1057/jdg.2010.31.

Chen, Huifa, Qingliang Tang, Yihong Jiang, and Zhijun Lin. 2010. "The Role of International Financial Reporting Standards in Accounting Quality: Evidence from the European Union." Journal of International Financial Management and Accounting 21(3): 220 78.

Christensen, Hans B et al. 2015. "Incentives or Standards: What Determines Accounting Quality Changes around IFRS Adoption? Incentives or Standards: What Determines Accounting Quality Changes around IFRS Adoption?" European Accounting Review 24(1): 31-61. http://dx.doi.org/10.1080/09638180.2015.1009144.

Chua, Yi Lin(Elaine), Chee Seng Cheong, and Graeme Gould. 2012. "The Impact of Mandatory IFRS Adoption on Accounting Quality: Evidence from Australia." Journal of International Accounting Research 11(1): 119-46. 
D’Arcy, Anne, and Ann Tarca. 2018. "Reviewing IFRS Goodwill Accounting Research: Implementation Effects and Cross-Country Differences." International Journal of Accounting.

Dechow, Patricia, Weili Ge, and Catherine Schrand. 2010. "Understanding Earnings Quality: A Review of the Proxies, Their Determinants and Their Consequences." Journal of Accounting and Economics 50(2-3): http://dx.doi.org/10.1016/j.jacceco.2010.09.001.

DeFond, Mark L., and James Jiambalvo. 1994. "Debt Covenant Violation and Manipulation of Accruals." Journal of Accounting and Economics 17(1-2): 145-76.

Dimitropoulos, Panagiotis E, Dimitrios Asteriou, Dimitrios Kousenidis, and Stergios Leventis. 2013. "Advances in Accounting, Incorporating Advances in International Accounting The Impact of IFRS on Accounting Quality: Evidence from Greece." International Journal of Cardiology 29(1): 108-23. http://dx.doi.org/10.1016/j.adiac.2013.03.004.

Edeigba, Jude, Christopher Gan, and Felix Amenkhienan. 2019. "The Influence of Cultural Diversity on the Convergence of IFRS: Evidence from Nigeria IFRS Implementation." Review of Quantitative Finance and Accounting. https://doi.org/10.1007/s11156-01900837-0.

Francis, Jere R., and Dechun Wang. 2008. "The Joint Effect of Investor Protection and Big 4 Audits on Earnings Quality around the World." Contemporary Accounting Research 25(1).

Fuad, Fuad, Agung Juliarto, and Puji Harto. 2019. "Does IFRS Convergence Really Increase Accounting Qualities? Emerging Market Evidence." Journal of Economics, Finance, and Administrative Science.

Gois, Alan Diogenes, Gerlando A.S.F de Lima, Nadia A. de Sousa, and Mara J.C. Malacrida. 2018. "The Effect of National Culture on the Relationship between IFRS Adoption and the Cost of Equity Capital '." Journal of International Accounting Research 17(3): 6985.

Gray, S.J. 1988. "Towards a Theory of Cultural Influence on the Development of Accounting Systems Internationally." ABACUS 24(I): 1-15.

Gray, Sidney J, Tony Kang, and Zhiwei Lin. 2015. "Earnings Management in Europe Post IFRS : Do Cultural Influences Persist?" Management International Review 55(6): 82756.

Han, Sam et al. 2010. "A Cross-Country Study on the Effect of National Culture on Earnings Management." Journal of International Business Studies 41: 123-41.

Han, Sam, Tony Kang, Stephen Salter, and Yong Keun Yoo. 2008. “A Cross-Country Study on the Effects of National Culture on Earnings Management." Journal of International Business Studies 41(1): 123-41. http://dx.doi.org/10.1057/jibs.2008.78. 
Hao, Jun, and Jennifer Yin. 2019. "Convergence to IFRS, Accounting Quality, and the Role of Regional Institutions: Evidence from China." Asian Review of Accounting.

Hassan, Omaima A G, Peter Romilly, Gianluigi Giorgioni, and David Power. 2009. "The Value Relevance of Disclosure : Evidence from the Emerging Capital Market of Egypt." International Journal of Accounting 44(1): 79-102. http://dx.doi.org/10.1016/j.intacc.2008.12.005.

Healy, Paul M. 1985. "The Effect of Bonus Schemes on Accounting Decisions.” Journal of Accounting and Economics 7(1-3): 85-107.

Hessayri, Manel, and Malek Saihi. 2015. "Monitoring Earnings Management in Emerging Markets: IFRS Adoption and Ownership Structure." Journal of Economic and Administrative Sciences 31(2): 86-108.

Hofstede, Geert. 2011. "Dimensionalizing Cultures: The Hofstede Model in Context Dimensionalizing Cultures: The Hofstede Model in Context." Online Readings in Psychology and Culture 2(1): 1-26.

IFRS Foundation, IFRS. 2018. "IFRS Foundation Annual Report 2018."

Ji, Xu dong, Wei Lu, and Wen Qu. 2017. "Voluntary Disclosure of Internal Control Weakness and Earnings Quality: Evidence From China." International Journal of Accounting 52(1): 27-44. http://dx.doi.org/10.1016/j.intacc.2017.01.007.

Junior, D.B.C.V, M.P Ohlson, I.M.E.C Lourenco, and G.A.S.F de Lima. 2018. "Mandatory Adoption of IFRS and Earnings Management in Emerging Countries: The Role of National Culture .o ISCTE-IUL.” XVII USP International Conference in Accounting.

Kanagaretnam, Kiridaran, Chee Yeow Lim, and Gerald J. Lobo. 2011. "Effects of National Culture on Earnings Quality of Banks." Journal of International Business Studies 42(6): 853-74.

Khan, Muhammad Asif, Dongmin Kong, Junyi Xiang, and Jian Zhang. 2019. "Impact of Institutional Quality on Financial Development: Cross-Country Evidence Based on Emerging and Growth-Leading Economies Impact of Institutional Quality on Financial Development: Cross-Country Evidence Based on Emerging and." Emerging Markets Finance and Trade 0(0): 1-17. https://doi.org/10.1080/1540496X.2019.1588725.

Lang, Mark, Jana Smith Raedy, and Michelle Higgins Yetman. 2003. "How Representative Are Firms That Are Cross-Listed in the United States? An Analysis of Accounting Quality." Journal of Accounting Research 41(2): 363-86.

Lang, Mark, Jana Smith Raedy, and Wendy Wilson. 2006. "Earnings Management and Cross Listing: Are Reconciled Earnings Comparable to US Earnings?" Journal of Accounting and Economics 42(1-2): 255-83.Leuz, Christian. 2003. "IAS versus US GAAP: Information Asymmetry Based Evidence from Germany\&\#039;s New Market.” Journal of Accounting Research 41(3): 445. 
Liu, Chunhui, Lee J Yao, Nan Hu, and Ling Liu. 2011. “The Impact of IFRS on Accounting Quality in a Regulated Market: An Empirical Study of China.” Journal of Accounting, Auditing \& Finance 4(26): 659-76.

Maradona, Agus Fredy, and Parmod Chand. 2018. "The Pathway of Transition to International Financial Reporting Standards (IFRS) in Developing Countries: Evidence from Indonesia." Journal of International Accounting, Auditing and Taxation 30(December 2017): 57-68. https://doi.org/10.1016/j.intaccaudtax.2017.12.005.

McNichols, Maureen F. 2000. 19 Journal of Accounting and Public Policy Research Design Issues in Earnings Management Studies.

Paredes, Angel A.P, and Clark Wheatley. 2017. "The Influence of Culture on Real Earnings Management." International Journal of Emerging Markets 12(1): 38-57.

Reichelt, Kenneth J., and Dechun Wang. 2010. "National and Office-Specific Measures of Auditor Industry Expertise and Effects on Audit Quality." Journal of Accounting Research 48(3): 647-86.

Watts, Ross L, Jerold L Zimmerman, and Standards L Ross Watts. 1978. "Towards a Positive Theory of the Determination of Accounting Standards Towards a Positive Theory of the Determination of Accounting." Source: The Accounting Review THE ACCOUNTING REVIEW 53(I):112-34 http://www.jstor.org/stable/245729\%0Ahttp://about.jstor.org/terms.

Wijayana, Singgih, and Sidney J Gray. 2019. "Institutional Factors and Earnings Management in the Asia - Pacific: Is IFRS Adoption Making a Difference?" Management International Review 59(2):307-34. https://doi.org/10.1007/s11575-018-0371-1.

Zeghal, Daniel, and Zouhour Lahmar. 2018. "The Effect of Culture on Accounting Conservatism During Adoption of IFRS in the EU." International Journal of Accounting \&Information Management 26(2): 311-30. 
The Indonesian Journal of Accounting Research - Jan, Vol. 23, No.1, 2020

intentionally blank 